\title{
Frequency of Elevated Blood Pressure Associated With Physical Activity and Dietary Patterns among School Going Adolescents in Karachi: A Cross Sectional Survey
}

PEREIRA Felicianus Anthony ${ }^{1}$, QADIR Jumana Abdul ${ }^{2}$, KAMRAN Sajida ${ }^{3}$

Corresponding author: Felicianus Anthony Pereira, E-mail: f.pereira93@hotmail.com

Abstract

2. Institute of Physical Therapy \& Rehabilitation, Jinnah Sindh Medical University, Karachi, Pakistan

Background: Studies have suggested that atherosclerotic changes take place in the body since childhood due to altered dietary patterns and sedentary lifestyle. It is critical to identify gap areas and update current literature to produce effective changes in our lifestyle.

Study design: A cross-sectional survey conducted among school going adolescents in Karachi.

Methods: A cross sectional study was performed in three different schools of Karachi. A sample size of 288 was drawn through non-probability, purposive sampling technique. Students were given a questionnaire comprising of questions regarding their physical activity levels, dietary patterns and knowledge regarding blood pressure. Blood pressure and Body Mass Index data was also recorded.

Results: Mean age of participants was $14.10 \pm 1.097$. Of the 288 students that participated in this study (122 boys and 166 girls), 227 were normal for hypertension status (93 boys and 134 girls), 27 were pre-hypertensive ( 7 boys and 20 girls), and 34 were hypertensive ( 22 boys and 12 girls). Mean systolic blood pressure was $112.73 \pm 13.49$, and mean diastolic blood pressure was 71.25 \pm 13.03 . Awareness among participants was high regarding hypertension being linked to the foods they consumed (62.8\%).

Conclusion: Our study did not show strong correlation between physical activity and dietary patterns, with status of hypertension. Screening programs should be conducted in schools to monitor blood pressure and body mass index. High risk groups should be approached and advised for lifestyle modification..

Keywords: hypertension, adolescents, life style,

\section{Introduction}

With a worldwide prevalence of $40.8 \%$, hypertension (HTN) is a rapidly increasing public health problem. It is now recognized as one of the major risk factors for cardiac, cerebrovascular and chronic kidney disease. ${ }^{1}$ Every year, elevated blood pressure leads to $54 \%$ of strokes, $47 \%$ of ischemic heart disease (IHD) and 7.6 million premature deaths. ${ }^{2}$ There is limited updated information on the prevalence of hypertension in Pakistan. ${ }^{1}$ In recent times, HTN has been started to be acknowledged as an important pediatric crisis. ${ }^{3}$ The definition of "normal blood pressure" is given as Systolic Blood Pressure (SBP) and Diastolic Blood Pressure (DBP) values $<90$ th percentile according to age, sex and height. "Prehypertension" or elevated blood pressure for adolescents is defined as BP $\geq 120 / 80 \mathrm{~mm} \mathrm{Hg}$ to $<95$ th percentile, or $\geq 90$ th and $<95$ th percentile, whichever was lower. 4 Evidence documents that lifestyle choices in childhood associated with risk factors which include dietary habits and physical activity levels contribute to elevated blood pressure in children. ${ }^{5}$ Furthermore, early origin of risk factors during adolescence and death due to IHD is also increasing. However, knowledge regarding this growing epidemic and its high prevalence is deficient among adolescents. ${ }^{2}$

A survey conducted by the World Health Organization (WHO) in 2010 revealed that $81 \%$ of youths between ages of 11-17 were not sufficiently physically active. Girls performed fewer physical activities than boys ( $84 \%$ vs.
$78 \%$ ). WHO claims that sedentary behavior at home contributes to the low levels of physical activity. Similarly, rise in the use of passive modes of transportation is also responsible for insufficient physical activity. ${ }^{6}$

Dietary intake characteristics like; frequency of eating, portion sizes, energy density, high fat, sodas and sugar intake contribute to altered dietary patterns. ${ }^{7}$ Pathological studies show that there is a positive correlation between atherosclerotic lesions and risk factors such as low density lipoprotein cholesterol, triglyceride, SBP \& DBP, body mass index (BMI), and cigarette smoking. ${ }^{5}$ Hence, it is important to evaluate diet for these characteristics in adolescence because it predicts dietary intake in adult life which can thereby cause a risk of chronic diseases.

The purpose of this research was to assess the frequency of elevated blood pressure associated with lifestyle choice in school going adolescents and assess awareness of the modifiable risk factors.

With rate of mortality due to non-communicable diseases rising to 52 million by 2030 it is crucial for our present generation of adolescents to be aware of elevated blood pressure and their relative lifestyle. ${ }^{2}$

According to author's knowledge, elevated blood pressure in adolescents is under reported in our part of the world. ${ }^{8}$ Two major contributing factors are: altered dietary patterns due to ease of access to fast food, ${ }^{9}$ and increased screen time leading to sedentary lifestyle. 


\section{Methods}

Permission to conduct this study was obtained from Institute of Physical Medicine \& Rehabilitation, Dow University of Health Sciences. (Reference no. IPM\&R/DUHS-17/061)

The cross-sectional survey was conducted on children aged 13 to 16 and enrolled in public and private schools in Karachi, Pakistan. It was performed in compliance with declaration of Helsinki. Principals, teachers and students were briefed about the study. They were explained about the purpose of the study and were assured strict confidentiality. Consent was obtained from parents, as participants in the study were below legal age. Children, teachers, and parents (through consent forms) were informed of the procedure of the study. Sample size was calculated at 282 with confidence interval of $95 \%$ using OpenEpi version 3.01. Data was obtained via a self-design questionnaire.

Blood pressure was measured using a mercury sphygmomanometer (Certeza Desk Type CR-2001). Children were in a calm environment before readings were taken. Appropriate cuff size was used during the research. Blood pressure measurements were taken with the arm extended over the table, at the level of the heart. ${ }^{10}$ Two readings were taken with 5 minutes' interval between each reading, and the average was calculated. 10 Classification of BP percentiles were determined using normative tables obtained from National Health and Nutrition Examination Survey data. The 95th percentile was used as a measure of elevated blood pressure for the adolescents' gender, height and weight.

Weight was measured using an electronic weighing scale (Senior Model DB-6020 - accurate to $0.1 \mathrm{~kg}$ ). Children were weighed wearing light clothes and no shoes. Standing height was measured with shoes removed and the child facing away from the wall, with the heels, buttocks, shoulders and head touching the wall and the child looking ahead and the external auditory meatus and lower margin of the orbit aligned horizontally. ${ }^{2}$ Height was measured using a tape measure (accurate to $\pm 1 / 2 \mathrm{~cm}$ ). Measurements were recorded between 8:30 a.m. and 11:00 a.m. ${ }^{11}$ Weight and height were converted to metric measurements to determine the BMI, which is calculated by weight $(\mathrm{kg})$ divided by height squared $\left(\mathrm{m}^{2}\right)$.

\section{Results}

Children included in the study were between 13 to 16 years of age. Mean age of participants was $14.10 \pm 1.097$. Of the 288 students that participated in this study, 27 were pre- hypertensive, and 34 were hypertensive $(9.4 \%$ and $11.8 \%$ respectively). (Table 1) Gender wise distribution of status of HTN is shown in Figure 1. Mean SBP was $112.73 \pm 13.49$, and mean DBP was $71.25 \pm 13.03$.
Table 1: status of HTN

\begin{tabular}{|l|l|l|}
\cline { 2 - 3 } \multicolumn{1}{c|}{} & Frequency & Percent \\
\hline Status of HTN & \multicolumn{2}{|c|}{} \\
\hline Normal & 227 & 78.8 \\
\hline Pre-hypertensive & 27 & 9.4 \\
\hline Hypertensive & 34 & 11.8 \\
\hline Total & 288 & 100 \\
\hline \multicolumn{2}{|c|}{ gender female }
\end{tabular}

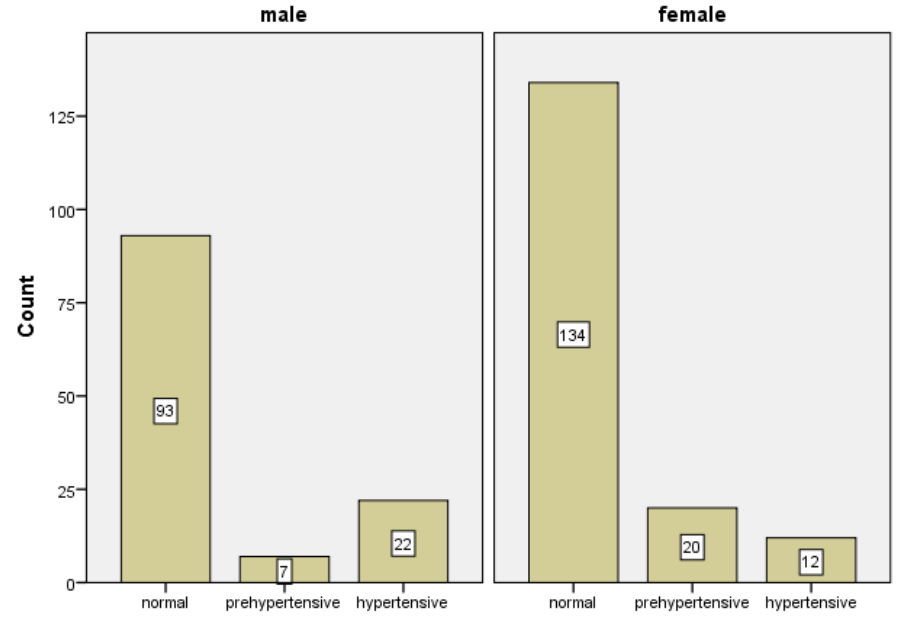

status of HTN

Figure 1

The association found between status of HTN and status of BMI was statistically significant ( $p$ value $=0.000$ ). (Table 2) Cross tabulation of status of hypertension with frequency of sitting and lying down showed no statistical significance $(p$-value $=0.878)$. Statistical significance $(p-$ value $=0.001$ ) was also noted between cell phone usage and status of hypertension. Weak association (pvalue $=0.936$ ) between cigarette smoking and status of hypertension was noted in this study. 285 participants did not smoke at all. 2 participants smoked to a moderate extent; both had normal HTN status. Statistical significance $\quad(p$-value $=0.007)$ was found between consummation of soft drinks, and the status of hypertension (Table 3 ).

Table 2: association of status of BMI with status of HTN

\begin{tabular}{|l|c|c|c|c|}
\hline $\begin{array}{l}\text { Status of } \\
\begin{array}{l}\text { Status } \\
\text { of BMI }\end{array}\end{array}$ & Normal & $\begin{array}{c}\text { Pre- } \\
\text { hypertensive }\end{array}$ & Hypertensive & Total \\
\hline Underweight & 113 & 11 & 10 & 134 \\
\hline Normal & 95 & 13 & 11 & 119 \\
\hline Overweight & 17 & 1 & 10 & 28 \\
\hline Obese grade I & 2 & 2 & 3 & 7 \\
\hline Total & 227 & 27 & 34 & 288 \\
\hline
\end{tabular}


Table 3: association of status of hypertension with sitting/lying down, cell phone usage, soft drinks consumption and cigarette smoking

\begin{tabular}{|c|c|c|c|c|c|}
\hline Status of HTN & \multicolumn{4}{|c|}{ Factors (Frequency) } & P-value \\
\hline & \multicolumn{4}{|c|}{ Sitting/lying down } & \multirow{5}{*}{0.878} \\
\hline & $\begin{array}{l}\text { Not } \\
\text { at } \\
\text { all }\end{array}$ & $\begin{array}{c}\text { To a small } \\
\text { extent }\end{array}$ & \begin{tabular}{c|} 
To a \\
moderate \\
extent
\end{tabular} & $\begin{array}{c}\text { To a } \\
\text { large } \\
\text { extent }\end{array}$ & \\
\hline Normal & 3 & 84 & 110 & 30 & \\
\hline Pre-hypertensive & 1 & 12 & 11 & 3 & \\
\hline \multirow[t]{3}{*}{ Hypertensive } & 0 & 12 & 17 & 5 & \\
\hline & \multicolumn{4}{|c|}{ Cell phone usage } & \multirow{5}{*}{0.001} \\
\hline & $\begin{array}{l}\text { Not } \\
\text { at } \\
\text { all }\end{array}$ & $\begin{array}{c}\text { To a small } \\
\text { extent }\end{array}$ & $\begin{array}{c}\text { To a } \\
\text { moderate } \\
\text { extent }\end{array}$ & $\begin{array}{c}\text { To a } \\
\text { large } \\
\text { extent }\end{array}$ & \\
\hline Normal & 18 & 89 & 82 & 38 & \\
\hline Pre-hypertensive & 9 & 9 & 6 & 3 & \\
\hline \multirow[t]{3}{*}{ Hypertensive } & 1 & 17 & 9 & 7 & \\
\hline & & Soft drinks & consumptio & & \multirow{5}{*}{0.007} \\
\hline & $\begin{array}{l}\text { Nev } \\
\text { er }\end{array}$ & $\begin{array}{c}1 \text { time per } \\
\text { week }\end{array}$ & \begin{tabular}{c|} 
3-4 times \\
per week
\end{tabular} & $\begin{array}{c}\text { or more } \\
\text { times } \\
\text { per day }\end{array}$ & \\
\hline Normal & 79 & 116 & 24 & 8 & \\
\hline Pre-hypertensive & 11 & 15 & 1 & 0 & \\
\hline \multirow[t]{3}{*}{ Hypertensive } & 7 & 16 & 11 & 0 & \\
\hline & \multicolumn{4}{|c|}{ Cigarette smoking } & \multirow{5}{*}{0.936} \\
\hline & $\begin{array}{l}\text { Not } \\
\text { at } \\
\text { all } \\
\end{array}$ & $\begin{array}{c}\text { To a } \\
\text { moderate } \\
\text { extent }\end{array}$ & \multicolumn{2}{|c|}{ To a large extent } & \\
\hline Normal & 224 & 2 & \multicolumn{2}{|l|}{1} & \\
\hline Pre-hypertensive & 27 & 0 & \multicolumn{2}{|l|}{0} & \\
\hline Hypertensive & 34 & 0 & \multicolumn{2}{|l|}{0} & \\
\hline
\end{tabular}

\section{Discussion}

In this study the prevalence of $\mathrm{BP}>95$ th percentile is $11.81 \%$, BP between 90th and 95th percentile is $9.38 \%$. These are quite similar with the results of previous studies. ${ }^{12}{ }^{13}$ Various studies in different parts of the world report a prevalence ranging from $0.46 \%$ to $21.8 \%$. The reason for this might be due to the difference in the study group's age and ethnicity. ${ }^{14}$ It is worth mentioning that the difference in number of times the measurements were taken reduced the prevalence from $13 \%$ to $1 \%$ between the first and third visits. ${ }^{15}$

In this study, obesity, altered food habits and physical inactivity are three risk factors that have been found to be independently associated with high BP. Results of a study conducted by Cinteza and Balgradean and Rahman et al. support the association between obesity and elevated blood pressure. ${ }^{16}$ A study conducted on Pakistani students had the same findings. ${ }^{17}$ Another study suggested that there is a shift in the arterial pressure control mechanism of diuresis and naturesis due to activation of sympathetic nervous system, in obese adolescents which ultimately leads to higher BP levels. ${ }^{18}$ In our study no statistically significant association was noted between consumption of junk food and that status of HTN. Similar results were found in a study conducted by Jasmine s sunder et al. ${ }^{19}$
However, in a study conducted by Sentamizh Prasad et al. there was a significant statistical association between the former two variables. ${ }^{2}$ As with the results of other studies, our research indicated strong statistical significance between increased screen time and elevated blood pressure. $^{20} 21 \quad 1822{ }^{23}{ }^{24}$ Due to reduced physical activity, there is dysregulation of body weight, insulin usage and indirectly blood lipids, glucose and clotting factors get deranged, altering the blood vessels and thereby altering blood pressure. ${ }^{25}$

Knowledge about HTN was high among participants. $89.2 \%$ had been informed by a teacher or a guardian about BP; this contrasts with the findings of Prasad et al study, where adolescents had a poor understanding of knowledge of BP. ${ }^{2}$ Majority of participants $(62.8 \%)$ were aware of BP being linked to the foods they consumed.

Limitations of our research were that BP measurements were taken twice; assessment of dietary patterns was done via questionnaire, based on responses from participant's memory, which may be subject to recall bias. No observation was done to assess levels of physical activity. Also, a stratified sampling technique would have been more appropriate, as the participants in our study were from Dawoodi Bohra community, and is not a complete representation of the different ethnic groups of adolescents in the country.

Informative sessions can be conducted in schools to inform children and parents about relation between obesity and hypertension. Intervention strategies should be implemented at national level, such as the banning of soft drinks at schools by the Punjab government ${ }^{1}$ to reduce the chances of cardiovascular diseases developing later in life.

\section{Conclusion}

We conclude that there is no strong correlation between physical activity and dietary patterns with status of hypertension among adolescents. However, screening programs should be conducted in schools to monitor blood pressure and BMI. Ultimately, high risk groups should be approached and advised for lifestyle modification.

\section{Acknowledgement}

The authors would like to acknowledge all school children and their caregivers for their co-operation in the study.

\section{Conflict of interest}

The authors report no conflict of interest.

\section{Funding}

No funding was obtained for this study. 


\section{References:}

1. Shafi ST, Shafi T. A survey of hypertension prevalence, awareness, treatment, and control in health screening camps of rural central Punjab, Pakistan. Journal of epidemiology and global health. 2017 Jun 1;7(2):135-40.

2. Prasad S, Masood J, Srivastava AK, Mishra P. Elevated blood pressure and its associated risk factors among adolescents of a North Indian City-A cross-sectional study. Indian journal of community medicine: official publication of Indian Association of Preventive \& Social Medicine. 2017 Jul;42(3):155.

3. Diaz A, Calandra L. High blood pressure in school children and adolescents in Argentina over the past 25 years: A systematic review of observational studies. Arch Argent Pediatr. 2017 Feb 1;115(1):5-11.

4. Flynn JT, Kaelber DC, Baker-Smith CM, Blowey D, Carroll AE, Daniels SR, de Ferranti SD, Dionne JM, Falkner B, Flinn SK, Gidding SS. Clinical practice guideline for screening and management of high blood pressure in children and adolescents. Pediatrics. 2017 Sep 1;140(3).

5. Kavey RE, Daniels SR, Lauer RM, Atkins DL, Hayman LL, Taubert K. American Heart Association guidelines for primary prevention of atherosclerotic cardiovascular disease beginning in childhood. Circulation. 2003 Mar 25;107(11):1562-6.

6. Organization. WH. Physical activity. 2017 [cited 201728 August]; Available from: http://www.who.int/mediacentre/factsheets/fs385/en/

7. Winkvist A, Hultén B, Kim JL, Johansson I, Torén K, Brisman J, Forslund HB. Dietary intake, leisure time activities and obesity among adolescents in Western Sweden: a cross-sectional study. Nutrition journal. 2015 Dec $1 ; 15(1): 41$

8. Ghaffar A, Reddy KS, Singhi M. Burden of noncommunicable diseases in South Asia. Bmj. 2004 Apr 1;328(7443):807-10.

9. Jiao J, Moudon AV, Kim SY, Hurvitz PM, Drewnowski A. Health implications of adults' eating at and living near fast food or quick service restaurants. Nutrition \& diabetes. 2015 Jul;5(7):e171-.

10. Pickering TG, Hall JE, Appel LJ, Falkner BE, Graves J, Hill MN, Jones DW, Kurtz T, Sheps SG, Roccella EJ. Recommendations for blood pressure measurement in humans and experimental animals: part 1: blood pressure measurement in humans: a statement for professionals from the Subcommittee of Professional and Public Education of the American Heart Association Council on High Blood Pressure Research. Hypertension. 2005 Jan 1;45(1):142-61.

11. de Almeida MM, Guimarães RA, Jardim PC, Sousa AL, de Souza MM. Association between arterial hypertension and nutritional status in adolescents from Goiânia, Goiás, Brazil. PloS one. 2017 Dec 18;12(12):e0188782.

12. Xu H, Hu X, Zhang Q, Du S, Fang H, Li Y, Ma J, Li T, Du L, Guo H, Xu G. The association of hypertension with obesity and metabolic abnormalities among Chinese children. International journal of hypertension. 2011;2011.
13. Schommer VA, Barbiero SM, Cesa CC, Oliveira R, Silva AD, Pellanda LC. Excess weight, anthropometric variables and blood pressure in schoolchildren aged 10 to 18 years. Arquivos brasileiros de cardiologia. 2014 Apr;102(4):312-8.

14. Bancalari R, Diaz C, Martinez-Aguayo A, Aglony M, Zamorano J, Cerda V, Fernandez M, Garbin F, Cavada G, Valenzuela M, Garcia H. Prevalence of hypertension in school age children and its association with obesity. Revista medica de Chile. 2011 Jul;139(7):872.

15. Lauer RM, Mahoney LT, Clarke WR. Tracking of blood pressure during childhood: the Muscatine Study. Clinical and Experimental Hypertension. Part A: Theory and Practice. 1986 Jan 1;8(4-5):515-37.

16. CINTEZA E, BALGRADEAN M. Hypertension in Romanian children and adolescents: a cross-sectional survey. Maedica. 2013 Mar;8(1):5.

17. Rahman AJ, Qamar FN, Ashraf S, Khowaja ZA, Tariq SB, Naeem H. Prevalence of hypertension in healthy school children in Pakistan and its relationship with body mass index, proteinuria and hematuria. Saudi Journal of Kidney Diseases and Transplantation. 2013;24(2):408.

18. Ostrowska-Nawarycz L, Nawarycz T. Original article Prevalence of excessive body weight and high blood pressure in children and adolescents in the city of Łódź. Kardiologia Polska (Polish Heart Journal). 2007;65(9):107987.

19. Sundar JS, Adaikalam JM, Parameswari S, Valarmarthi S, Kalpana S, Shantharam D. Prevalence and determinants of hypertension among urban school children in the age group of 13-17 years in, Chennai, Tamilnadu. Epidemiol. 2013;3(130):2161-1165.

20. Kar S, Khandelwal B. Fast foods and physical inactivity are risk factors for obesity and hypertension among adolescent school children in east district of Sikkim, India. Journal of natural science, biology, and medicine. $2015 \mathrm{Jul} ; 6(2): 356$.

21. Sundar JS, Adaikalam JM, Parameswari S, Valarmarthi S, Kalpana S, Shantharam D. Prevalence and determinants of hypertension among urban school children in the age group of 13-17 years in, Chennai, Tamilnadu. Epidemiol. 2013;3(130):2161-1165.

22. Gupta AK, Ahmad AJ. Childhood obesity and hypertension. Indian pediatrics. 1990;27(4):333-7.

23. Carter MA. Do childhood excess weight and family food insecurity share common risk factors in the local environment? An examination using a Quebec birth cohort (Doctoral dissertation, Université d'Ottawa/University of Ottawa).

24. Musaiger AO, Al-Mannai M, Zagzoog N. Association between food intake frequency and obesity among adolescent girls in Saudi Arabia. International journal of adolescent medicine and health. 2014 Feb 1;26(1):145-7.

25. Federation WH. [cited 2016 feb 26]; Available from: http://www.world-heart-federation.org/cardiovascularhealth/cardiovascular-disease-risk-factors/physical-inactivity 